\title{
THE INFLUENCE OF COMPETITIVENESS ON START-UP IN SMES SEGMENT
}

\author{
Ján Dvorský1, Martin Čepel², Mihaela Simionescü, \\ Pavol Durana ${ }^{4}$
}

1 Tomas Bata University in Zlin, Faculty of Management and Economics, Department of Business Administration, Czech Republic, ORCID: 0000-0002-6078-2636,j1dvorsky@utb.cz;

2 Paneuropean University in Bratislava, Faculty of Economics and Business, Slovak Republic, ORCID: 0000-00026382-9899, martin.cepel@paneurouni.com;

3 Romanian Academy, Institute for Economic Forecasting, Romania, ORCID: 0000-0002-6124-2172, mihaela.simionescu@ipe.ro;

4 University of Žilina, Faculty of Operation and Economics of Transport and Communications, Slovak Republic, ORCID: 0000-0001-5975-1958, pavol.durana@fpedas.uniza.sk.

\begin{abstract}
The paper aims to identify important factors for competitiveness (CF - Competitive environment, FF - Narrower business environment), which impact start-up in a segment of SMEs. In regards to the defined aim, survey-based research was conducted with enterprises operating in the SME segment. Three 312 enterprises in the Czech Republic and 329 enterprises in the Slovak Republic were approached during this research. The multiple linear regression was used: (a) to quantify the relationship between the variables, (b) to identify the most critical indicator of QBE, and also to verify the scientific hypothesis. The competitive environment has a significant impact on the quality of the business environment in the SME segment. The authors found that the selected factors (CF and FF) were statistically significant. The competitive environment (CF) has a greater impact on the quality of the business environment than the narrower business environment (FF). Human capital represented by employees and the adequacy of supplier prices are indicators that have a significant impact on the quality of the business environment in the SME segment. The most critical CF indicator is that the suppliers of SMEs demand reasonable prices for their products and services. On the contrary, the least significant indicator is the intensity of competition in the sector. The most important indicator of a narrower business environment is the contribution of employees in achieving business goals. On the opposite, the least important indicator of a narrower business environment is the support of suppliers to meet the business goals of SMEs.
\end{abstract}

Keywords: Competitiveness, start-up, small and medium-sized enterprises.

JEL Classification: L126, M13.

APA Style Citation: Dvorský, J., Čepel, M., Simionescu, M., \& Durana, P. (2021). The Influence of Competitiveness on Start-up in SMEs Segment. E\&M Economics and Management, 24(1), 102-117. https://doi.org/10.15240/tul/001/2021-1-007

\section{Introduction}

In a global economy, competition is the primary driver of market competitiveness. "Globalization causes large-scale changes in the technological, economic, political, and social fields of social development. These changes have a contradictory impact on the development of national economies and their competitiveness. Ceteris paribus, there is a tight interrelation between country's economic competitiveness and a rate of its economic growth: the higher the rates of economic growth in the country, the bigger the chance for an increase in its national competitiveness and vice versa" Fyliuk et al. (2019). In this context, Ivanová and Čepel (2019) state that the key factor of the states' increasing competitiveness is assumed to be the innovation performance of enterprises, which is projected through innovative business processes into the innovation performance of the economy as a whole. 
The global competition put significant pressure on SMEs to make improvements in terms of efficiency cost and value-added services to meet market demand (Tan et al., 2006). These new requirements imposed the reconsideration of competitive strategies.

Newly created firms contribute to the economic development of economies and employment growth (Bilan et al., 2017). The decision to form a new company is based on subjective factors as the business environment also on personal reasons, derived from the individual's personality traits and motivation.

That one key factor that is taken into account by entrepreneurs when starting a new business is related to the business environment of the country in which the firm will be located (Krajnakova et al., 2018).

The quality of business environment is comprehensive concept, where besides economic factors such as development of fundamental macroeconomic indicators (GDP growth, development in unemployment, etc) and political factors (state of bureaucracy, quality of legal environment, etc) have an important role the factors related to competitive environment (suppliers and buyers power, barriers to entrance on the market, substitution issues, concurrence rivalry), broader business environment (social, economic, political and technological factors) and narrower business environment (Conorto et al., 2014; ŠabićLipovača et al., 2016; Lewandowska \& Stopa, 2019).

In this article, we examine the impact of competitive environment described by new competitors, level of competition in the SME's industry, the relationships with clients and suppliers in terms of prices on starting a business. The narrower business environment is focused on main actors: direct competitors, customers, suppliers, and employees. A good relationship with customers, suppliers, and employees correlated with the lack of serious threats from competitors could support a successful business model for SMEs. The originality and excellence of our research lie in the fact that we examined the opinions of entrepreneurs, i.e., people who are active and active in the business environment. These people also faced a decision to start a business a few years ago.

The structure of our contribution is as follows. After this introduction, the paper presents a theoretical background focusing on studies from the literature that assess the impact of the competitive environment on SMEs businesses. This chapter also introduces the factors that influence the start of business. After this section, empirical research based on a survey is made using enterprises from the Czech Republic and the Slovak Republic operating in the SME segment. After the presentation of results and discussions, the last part of the paper provides conclusions.

\section{Theoretical Background}

The motives that determine the start of business have been the subject of much research. Shaykhutdinova et al. (2015) state that expertise, intellect, ability to organize and manage, communicativeness, culture, ethical, and physical skills can positively influence the intention to become an entrepreneur. According to Staniewski and Awruk (2015), there are three most critical motivating factors: satisfaction with your life and the possibility of self-realization $(63 \%)$, the opportunity for a higher salary $(48 \%)$ and independence in decision-making (30\%). Other motivational factors are confirmation of its value $(21 \%)$ and higher social status $(5 \%)$. According to the authors, lack of experience, lack of capital, risk aversion, lack of technical knowledge, and tax aspects are the most critical barriers to business. Ketko and Akimova (2016) state that entrepreneurs are motivated by their emotional comfort, self-esteem, success, opportunity to be free, the opportunity to meet their own goals, and financial security.

Other authors emphasize other business motives, or factors influencing the decision to become an entrepreneur, e.g., the will to do something by yourself (Hikkerova et al., 2016; Kot et al., 2016), previous expertise, success and social motives (Ključnikov et al., 2019), higher education, innovation capacity and independence (Plotnikova et al., 2016; Buganova \& Moricova, 2017; Zygmunt, 2018; Belas et al., 2018; Cera et al., 2020).

The person believes in her actions rather than chance, luck, and random events might be a strong determinant of the decision to start a business. The determinants of start-up were related to commitment to make efforts to start a business and the flair to this process (BarbaSanchéz \& Atienza-Sahuquillo, 2011).

Demographic features are also relevant in the case of Romanian people who decide to 
open a business. Men are more eager to start a business compared to females because they consider the profit very important. The family background might also stimulate people to be entrepreneurs.

In the Czech and Slovak literature, the issue of motives for starting a business in the Small and Medium Enterprises segment has been developed to a limited extent.

According to Srpová and Řehoř (2010), motivation is an essential factor in business. People are motivated to succeed in business by various reasons, which divide into two groups: 1. push, that represents one has to deal with the situation, and business can play an essential role in this process; 2 . pull, that is existing opportunities, and their eventual use is a primary means of meeting needs, thereby motivating people to become entrepreneurs. In this regard, the authors state that the push reasons are stronger, but rather fade out and do not lead to extraordinary results. "Pull" reasons are more permanent and rarely go out. They are, therefore, the right reasons to start a business.

According to a GE Money Bank research 2010 in the Czech Republic, the desire to have more money is the strongest motive for starting a business. This impulse is vital for $70 \%$ of women and $75 \%$ of men. An important motivation is also the possibility to manage your time. Another essential motive for men is independence, and for women, the fear of firing a job (GE Money Bank, 2010). On the other hand, PwC research indicates that emotional reasons prevail over economic reasons when starting a business. According to the results of this research, the most crucial motive for starting a business is a desire for freedom in decision-making and a passion for a particular business plan. Only these emotional factors are followed by money and prestige (PwC, 2010).

Belas et al. (2016) examine the motives for starting a business in the Czech Republic on a sample of 1,141 entrepreneurs in 2015. The authors say that the most crucial cause for starting a business was the money motive, which was mentioned by $29 \%$ of Czech entrepreneurs respondents in the SME segment. Next, motives as follows: I wanted to have a job (22\%); I had no choice $(8 \%)$; and other reasons $(19 \%)$. In the category of other reasons, respondents cited many different motives: independence, freedom of decision, self-realization, entrepreneurship is a hobby, heritage, continuation of a family business and other individual reasons that cannot be categorized as answers 1 to 4 . answers: youthful indiscretion and I have refused to obey.

In the Slovak literature, this issue is addressed by Jakubec et al. (2011), who examined the motives for starting a business in the segment of young entrepreneurs in a sample of 324 respondents. Respondents identified the most frequent incentives for entrepreneurship as a desire to become independent $(58.64 \%)$ and to realize their dream/idea $(55.25 \%)$. These motifs are followed by so-called cynical motives, which include the possibility that the employment of respondents did not meet, and that they earn little in it (equal to $26.85 \%$ ). A new motive appears to be the claim that entrepreneurship was the only possibility of finding employment on the labor market with an $18.52 \%$ share in respondents' answers. This reason was more often cited by women than men $(22.41 \%$ versus $16.35 \%)$. Women also took over the family business more frequently $(8.62 \%$ vs. $4.33 \%)$. The motives are relatively homogeneous across different groups of respondents.

Besides these subjective determinants, some objective factors influence the start-up. Besides motivation and personal features, external factors like economic growth and uncertainty in the political environment could support the decision to start a business (Soetanto et al., 2010; Hudáková et al., 2018), financial measures are portrayed by Valaskova et al. (2018). For example, for South Africa, Naudé et al. (2008) identified few determinants for start-ups: education level, profit rates, access to formal bank finance, the economic size of the region. In the case of this country, profit was the strongest determinant for start-up, while the market size was negatively correlated to startup rates. Various factors might also determine the size of the start-up (Belas et al., 2014). For example, Arauzo-Carod and Segarra-Blasco (2005) considered the growth rate of industry and behavior of incumbent companies as essential factors in deciding the size of startups from Spanish manufacturing industries. Regional determinants are also crucial in establishing a start-up. For example, in the case of the UK regions in the period 2000-2004, Gleave and Mitra (2009) identified few regional determinants like spatial and sectoral changes 
in Value Added Tax registration rates. Moreover, besides geographical factors, there are also key determinants like income, skills, education, and structure of the private industry. In Germany, unemployment is considered an essential push-factor for start-up in an attempt to make a transition to self-employment (Niefert, 2010). Macroeconomic factors, such as inflation, labor productivity, tax rate and costs have significant impact on firms' and country's competitiveness (Rusu \& Roman, 2018).

The role of entrepreneurial activity varies across the stages of economic development. There is a U-shaped link between the rate of entrepreneurship and the level of economic development. Entrepreneurial activity has a positive impact on economic growth in developed countries, but the effect is negative for developing countries. Entrepreneurship also depends on the country's innovativeness. Entrepreneurship is also seen as a regional event that supposes networks and regional policies (Sternberg \& Wennekers, 2005; Abrhám et al., 2015).

All the SMEs are influenced by the globalizing competition that determines them to adapt the business models that are based on offering nature and networking strategy. The response of SMEs to globalizing competition was empirically analyzed by Westerlund et al. (2008) using two perspectives: collaboration strategy and offerings nature. The empirical study based on the analysis of 91 companies suggested that firms adopting a strategy of international expansion follow one of the four directions: specialization in personal offerings for clients with auxiliary services based on dyadic international links, distribution of offerings in a standardized form adding supplementary services, distribution of tailored offering using specific international multitier networks or distribution of basic offerings on the internal market using dyadic connections. There are few reasons for offshore outsourcing: lower labor cost, efficiency enhancement, flexibility in resource allocation for SMEs and suppliers, the development of a relationship through networks and alliances (Sinha et al., 2011).

Other studies explain the competitive advantage in the global framework by specific internal resources and capabilities that are developed (Maranto-Vargas \& Rangel, 2007). Moreover, Maranto-Vargas and Rangel (2007) found a positive connection between the development of internal capabilities (hard and soft technology) in SMEs from Mexico and business performance reflected through indicators like efficiency, growth rate, shareholders' financial returns, and productivity. Business competition and innovation positively contributed to the business performance in the SMEs from Portugal (Nunes et al., 2018). In this context, improvements in access to financial institutions and marketing networks are required by the aid of government assistance. Technology collaboration networks enhance innovation in SMEs through three factors at the macroeconomic level, microeconomic level, and sector level: the macroeconomic cycle, firm age, and industry life cycle (Fernández-Olmos \& Ramírez-Alesón, 2017). In this regard, Ključnikov et al. (2016) provide exciting conclusions that larger companies belonging to the segment of SMEs were more innovative, more active, and more autonomous in comparison to microenterprises.

According to Belas and Gabcova (2016), a higher level of customer satisfaction leads to additional purchases and increases business performance. The development of the relationship between companies and their clients and suppliers imposes the adaptation of business strategies. In this context, Boeck et al. (2009) showed that large buyers tend to utilize specific e-commerce tools and processes to maintain relationships with SME suppliers. These suppliers are forced to adapt to these requirements to maintain the relationship. Influential buyers might exploit SME suppliers controlling the price and volume of the goods and services from suppliers and also the number of suppliers (Wyld et al., 2012). Local SME suppliers could transfer expertise to their foreign transnational companies' clients (Chew \& Yeung, 2001; Meyer et al., 2018). Dependence and trust had a positive and significant impact on supplier performance for SMEs inside the supply chain relationship in the case of US companies (McDowell et al., 2010). The supply chain might be developed by promoting corporate social responsibility in SMEs. The supplier selection problem plays a vital role in supply chain management in the case of SMEs. The paper aims to discuss these issues. An intelligent system for supplier selection problem was proposed by Yadav et al. (2018) based on uncertainty elements in the decision process and multiple criteria. 
In this context, Dvorský et al. (2020) and Ajaz Khan et al. (2019) in their case studies examined the attitudes of entrepreneurs on the sources of strategic risk and the impact on the business environment in SME companies in the service sector in CR and SR. Their results showed that the Czech and Slovak entrepreneurs' perception did not statistically differ in any selected aspects of the business environment between the firms operating in service and non-service sectors. In all the cases business support was found insignificant.

Coppa and Sriramesh (2013) conducted a survey on a sample of 105 SMEs. Their results showed that a large number of SMEs viewed employees as the most important factor for the business environment whereas customers, suppliers, and business partners trailed far behind. Interestingly, the media, government, NGOs, and unions were relegated to the bottom of the list.

In this context, Islam (2019) in his research from South Korea said that the Instagram platform has a great impact not only on the business starters but on the consumers as well. It plays a greater role in linking and communicating with customers and firms rather than just a marketing tool. This research also claims that people starting a business through Instagram will be able to gather information and great amount of attention from their customers with a minimum cost.

Hess (2020) provides a comparative analysis on the neighboring entrepreneurial ecosystems in Bulgaria and Romania. Both countries maintain a highly educated workforce with high start-up skills and similar levels of global competitiveness in growing economies, while still facing low-risk acceptance and low opportunity perception. The author say that these two countries are good opportunities for starting a new business.

Conorto et al. (2014) define the levels and factors of the business environment. The levels of the business environment are: i. the wider business environment; ii. competitive environment; iii. narrower business environment. The authors state that the factors of the competitive environment include competitive rivalry, the strength of suppliers, the strength of customers, the barriers of entering the market. The narrower business environment contains factors such as direct competitors, customers, suppliers, and employees.
The wider business environment includes economic, political, social, and technological factors. The companies were also described by Maranto-Vargas and Rangel (2007) from their ability to compete in a global environment. It is recommended for SMEs oriented on knowledge creation and innovation to involve in international contexts. SMEs who focused on the development of internal capabilities could successfully compete large and multinational companies even if the financial resources are more limited. Moreover, Li et al. (2018) proposed a business model to explain how SMEs with limited capabilities and resources became competitive on the international market due to digital transformation. Huo et al. (2019) use a diamond model to explain export competitiveness of agricultural firms' in emerging markets finding labor cost and geographic economic factors highly influencing to competitiveness.

In the context of a medium level of global competitiveness of SMEs activating in the food industry in a region of Indonesia, Saleh et al. (2019) recommend the exploration of market opportunities, improvements in the entrepreneur's level of education to enhance ICT utilization and innovative activities. Innovations like worldwide web and Internet ensure higher connectivity and eliminate traditional barriers associated with businesses developed in more locations (Rowland-Jones et al., 2008). The SMEs' relationships with external agents and other companies enhance the creation and spread of knowledge through innovation (CapóVicedo et al., 2008). Innovation has deep and significant impact on firms' competitiveness through productivity increase as the study for the transitional markets show (Ngoc Mai et al., 2019).

The effect of SME's internal capabilities on competitive advantage was assessed by Gamez and Roliza (2019), also considering the firm age. In the case of Indonesia, SME's inner ability was strongly and positively correlated to competitive advantage. For SMEs with less than five years of activity, this connection is weak compared to old companies.

The competitive environment is also influenced by the interaction of factors like firms, regional development, governmental policies, and academic and research environment (Simionescu \& Naroș, 2019). Van Stel et al. (2019) explained the role of scale effects in the 
transmission of productivity effects from SMEs to big companies in terms of the dimension of firm and share of the SME sector in the overall economy. The cooperation between SMEs and large companies could contribute to industry competitiveness through three routes: supplier-driven cooperation, demand-driven cooperation, and partner-driven collaboration (Brink, 2017).

The technological and marketing capabilities of SMEs are developed by internal market competition and the entrepreneurial tendency at a global level. The development of these capabilities contributes to performance growth in international markets (Kliestik et al., 2018).

\section{Aim, Methodology and Data}

The aim of the paper is to identify important factors of competitiveness (CF - Competitive environment, FF - Narrower business environment) which impact start-up in segment of SMEs. The authors believe that the influence of the selected factors CF and FF on the QBE for starting a business is different according to the start-ups.

In regards to the defined aim, a surveybased research was conducted with enterprises operating in the SME segment. 312 enterprises in the Czech Republic and 329 enterprises in the Slovak Republic were approached during this research. Data collection took place in 2018. The authors define the start-up as the owner or senior manager of existing SME in $\mathrm{CR}$ or SR (hereinafter referred to as the "respondent"). The method of random choice using the "Randbetween" mathematical function was used to select enterprises from the "Albertina" database comprising enterprises in the Czech Republic. Slovak enterprises were randomly chosen from the "Cribis" database containing the list of enterprises, organizations, and entrepreneurs. The enterprises were approached via email asking them to fill out the online questionnaire.

The questionnaire was divided into the following parts: (a) socio-demographic characteristics - enterprise address, economic sector and size of enterprise; gender, age and educational level of the entrepreneur; (b) business environment factors - economic factors, political factors, technological and social factors, competitive environment, narrower business environment (direct competitors, customers, suppliers, and employees); (c) business environment quality indicators (QBEs). The authors of the article evaluated 9 indicators $(10.97 \%$ of all) from the questionnaire to fulfill the objective. The percentage of completed questionnaires that contained positive feedback responses reached $3.7 \%$. The survey also included a control question to prevent it from being automatically

\begin{tabular}{|c|c|c|c|}
\hline Factor & Indicator & Mean & SD \\
\hline \multicolumn{2}{|r|}{ CF Competitive environment } & 3.366 & 0.138 \\
\hline $\mathrm{CF}_{1}$ & New competitors entering the industry I operate in present an adequate risk. & 3.463 & 0.133 \\
\hline $\mathrm{CF}_{2}$ & The level of competition in the industry I operate in is normal. & 3.829 & 0.139 \\
\hline $\mathrm{CF}_{3}$ & My customers accept the prices of my products and services. & 2.780 & 0.158 \\
\hline $\mathrm{CF}_{4}$ & My suppliers' prices for products and services are adequate. & 3.390 & 0.125 \\
\hline \multicolumn{2}{|r|}{$\begin{array}{l}\text { FF Narrower business environment comprises direct competitors, customers, } \\
\text { suppliers, and employees }\end{array}$} & 3.616 & 0.133 \\
\hline $\mathrm{FF}_{1}$ & My competitors do not present a threat to my business. & 3.512 & 0.131 \\
\hline $\mathrm{FF}_{2}$ & My customers support me in doing business. & 3.561 & 0.131 \\
\hline $\mathrm{FF}_{3}$ & My suppliers intensively support me in doing business. & 3.659 & 0.129 \\
\hline $\mathrm{FF}_{4}$ & My employees intensively help me in achieving business goals. & 3.732 & 0.140 \\
\hline \multicolumn{2}{|r|}{ QBE } & \multirow{2}{*}{2.780} & \multirow{2}{*}{0.162} \\
\hline QBE & The business environment in my country is suitable for starting a business. & & \\
\hline
\end{tabular}


filled by a computer. The responses to the indicators below were formulated as a Likert five-point scale: from 1 'completely disagree' to 5 'completely agree' with the statement. In accordance with the approach by Conorto et al. (2014), individual indicators were defined using the following statements (see Tab. 1) with the basic evaluation, as is mean and standard deviation (SD).

To fulfill the aim, hypotheses were formulated:

H1: Competitive environment is a statistically significant factors and determines the quality of the business environment of the segment of SMEs.

H2: Narrower business environment (comprises direct competitors, customers, suppliers, and employees) is a statistically significant factors and determines the quality of the business environment of the segment of SMEs.

The multiple linear regression (MLR) was used: (a) to quantify the relationship between the variables, (b) to identify the most important indicator of QBE and also to verify the hypothesis $H$. The aim of apply LRMs is not to forecast the values of the dependent variable in our research. The LRMs are one of the appropriate statistical methods for factors evaluation because all variables (dependent: QBE and also independent: CF, FF), are metrics. The independent variables $\left(\mathrm{CF}_{1}, \ldots, \mathrm{FF}_{4}\right)$ must satisfy the assumptions of linearity (de Waal, 1977) and a normal distribution of data. We have verified the assumption of normality by the testing of the descriptive characteristics (skewness and kurtosis) using the z-test. If the value of the skewness or kurtosis of the $z$-test was between the values $<-2 ; 2>$, the assumption was accepted (Balcaen \& Ooghe, 2006). The assumption of a homoscedasticity (constant variance) of the errors was verified by Bartlett's test. This assumption was accepted when the Bartlett's statistics was lower than the critical value (CV). We used a coefficient correlation $(R)$ to verify the dependence between the QBE and CF or between FF and his indicators. We used the T-test to verify the significance of the coefficients in the regression model (Lancaster \& Hamdan, 1964). The test of the autocorrelation was not calculated because the author's sample data are not time series. The Shapiro-Wilk test (S-W test) was used to verify the normality distribution of errors. The normality distribution of errors is accepted when the $p$-value of S-W statistics is greater than the level of significance. The authors constructed the following LRMs:

General model with all independent indicators (GM1):

$$
Q B E=\beta_{0}+\beta_{1} \times C F_{1}+\ldots+\beta_{8} \times F F_{4}+\varepsilon_{t},
$$

where: QBE - the dependent variable (Quality of business environment); $\beta_{0}$ - constant; $\beta_{1}$, ..., $\beta_{8}$ - coefficients of independent variables $\mathrm{CF}_{1}, \ldots, \mathrm{CF}_{4}, \mathrm{FF}_{1}, \ldots, \mathrm{FF}_{4} ; \mathrm{CF}_{\mathrm{i}}$ - independent variables ( $\mathrm{CF}$ - the competitive environment; $\mathrm{FF}_{\mathrm{i}}$ - narrower business environment); $\varepsilon_{\mathrm{t}}$ - error term.

General model with factors (GM2):

$$
Q B E=\beta_{0}+\beta_{1} \times C F+\beta_{2} \times F F+\varepsilon_{t}
$$

where: QBE - the dependent variable (Quality of business environment); $\beta_{0}-$ constant, $\beta_{1}$, $\beta_{2}-$ coefficients of independent variables (CF, FF); CF, FF - independent variables (CF - competitive environment; FF - narrower business environment; $\varepsilon_{\mathrm{t}}$ - error term.

Partial model (PM1):

$$
\begin{aligned}
& C F=\beta_{0}+\beta_{1} \times C F_{1}+\beta_{2} \times C F_{2}+\beta_{3} \times \\
& \times C F_{3}+\beta_{4} \times C F_{4}+\varepsilon_{t},
\end{aligned}
$$

where: CF - the dependent variable (Competitive environment); $\beta_{0}$ - constant, $\beta_{1}, \ldots$, $\beta_{4}$ - coefficients of independent variables CFi; $\mathrm{CFi}$ - independent indicators of competitive environment; $\varepsilon_{\mathrm{t}}$ - error term.

Partial model (PM2):

$$
\begin{aligned}
& F F=\beta_{0}+\beta_{1} \times F F_{1}+\beta_{2} \times F F_{2}+\beta_{3} \times \\
& \times F F_{3}+\beta_{4} \times F F_{4}+\varepsilon_{t},
\end{aligned}
$$

where: FF - the dependent variable (Narrower business environment); $\beta_{0}$ - constant, $\beta_{1}, \ldots, \beta_{4}$ - coefficients of independent variables FFi; FFi - independent indicators of narrower business environment; $\varepsilon_{t}$ - error term.

The basic regression characteristics are: the coefficient of determination $\left(R^{2}\right)$, the multiple coefficient of correlation (MCC), F-test, VIF-test. The F-test verified the significance of the whole regression model (Zheng \& Yu, 2015). The presence of dependence between independent variables (multicollinearity) was 


\section{Fig. 1: Visualizations of partial and general models}

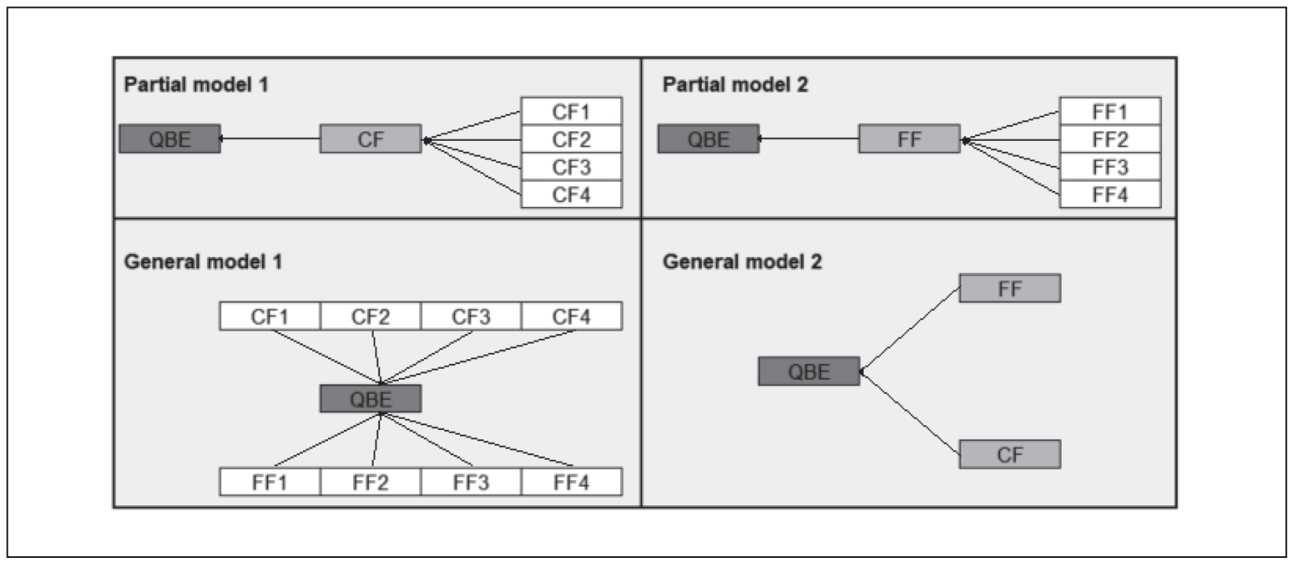

Source: own

verified using the Inflationary Variation Factor (VIF test) (O'Brien, 2007). If the value of the VIF test for the independent variable is less than 5 , then we note that the coefficient is not affected by multicollinearity (Stewart, 1987). The level of significance when applying the above tests is 0.05 . The calculations were performed using the SPSS Statistics software. Fig. 1 represents the general predictive and partial models of the relationships between the quality of the business environment and the selected independent variables.

The structure of respondents within the Czech Republic (312 enterprises) was the following: by time period of operating a business: 56 enterprises $1-5$ years, 48 enterprises $5-10$ years, 208 enterprises more than 10 years. Size of business: 258 micro-enterprises (up to 10 employees), 43 small enterprises (up to 50 employees), and 11 medium-sized enterprises (up to 250 employees). Highest attained education level of the entrepreneur: 50 high school without diploma, 135 high school with diploma, and 127 college education. Gender of entrepreneurs: 236 men, 76 women. The sectors of the economy: 109 service, 73 commerce, 53 manufacturing, 29 construction, 19 transportation, 9 agriculture companies, and 49 other (industry sector not mentioned in the questionnaire) companies.

The structure of respondents within the Slovak Republic (329 enterprises) was the following: by time period of operating a business:
104 enterprises 1-5 years, 78 enterprises 5-10 years, and 147 enterprises more than 10 years. Size of business: 234 micro-enterprises (up to 10 employees), 71 small enterprises (up to 50 employees), and 24 medium-sized enterprises (up to 250 employees). Highest attained education level of the entrepreneur: 10 high school without diploma, 95 high school with diploma, and 224 college education. Gender of entrepreneurs: 251 men, 78 women. The sectors of the economy: 122 service, 69 commerce, 51 manufacturing, 39 construction, 11 transportation, 20 agriculture companies, and 17 other companies.

The number of enterprises in the region (14 regions in CR and 8 regions on SR) that completed the questionnaire was proportionally comparable to the total number of SME enterprises in the region. The selection of the sample of SMEs included SMEs from the national capitals (CR: Prague and SR: Bratislava) with the largest number of completed questionnaires.

\section{Results and Discussion}

Linear trends between a dependent variable (QBE) and an independent variable $\left(\mathrm{CF}_{1}, \ldots\right.$, $\mathrm{FF}_{4}$ ) can be seen in results of graphical analysis (scatter plot). The linearity is confirmed for each indicator $\left(\mathrm{CF}_{1}, \ldots, \mathrm{FF}_{4}\right)$. The results of the assumption of homoscedasticity and normal data distribution are given in Tab. 2 . 


\section{Tab. 2: Verification of the assumptions of factor models}

\begin{tabular}{|c|c|c|c|c|c|c|}
\hline $\begin{array}{l}\text { Type of } \\
\text { model }\end{array}$ & $\begin{array}{l}\text { The assumption } \\
\text { of regression analysis }\end{array}$ & $\begin{array}{c}\text { Verification } \\
\text { tool }\end{array}$ & \multicolumn{4}{|c|}{ Independent variables } \\
\hline \multicolumn{3}{|c|}{ Indicators of factor - CF } & $\mathrm{CF}_{1}$ & $\mathrm{CF}_{2}$ & $\mathrm{CF}_{3}$ & $\mathrm{CF}_{4}$ \\
\hline \multirow{2}{*}{ PM 1} & Homoscedasticity & Bartlett's test & 0.012 & 0.041 & 0.008 & 0.006 \\
\hline & NDSS & Z-score & 1.255 & 0.782 & 0.805 & 1.681 \\
\hline \multicolumn{3}{|c|}{ Indicators of factor - FF } & $\mathrm{FF}_{1}$ & $\mathrm{FF}_{2}$ & $\mathrm{FF}_{3}$ & $\mathrm{FF}_{4}$ \\
\hline \multirow{2}{*}{ PM 2} & Homoscedasticity & Bartlett's test & 0.001 & 0.027 & 0.004 & 0.011 \\
\hline & NDSS & Z-score & 1.859 & 0.464 & 0.175 & 1.143 \\
\hline
\end{tabular}

Note: NDDS - Normal distribution of data set; CV of Bartlett's test is 7.8; level of significance $=0.05$.

The results showed (see Tab. 2), that the assumption of NDDS (Z-scores are in the interval values from -2 to 2 ) and the assumption of homoscedasticity ( $p$-values of Bartlett's test were less than level of significance) was accepted for each independent variable.

Tab. 3 summarizes the results of verifying the dependence between variables as well as testing the statistical significance of the estimated PMs coefficients.

The results of correlation matrixes (see Tab. 3) showed medium strong values of dependences between variables. The estimated coefficient of the independent variable is statistically significant if the $p$-value of the student's statistics (t-test) is higher than $0.05(\mathrm{t}$-stat $=1.934)$.

Tab. 4 shows the results of testing (according to MLR) the statistical significance of the thus designed factor models (PM1 and PM2).
Tab. 4 shows interesting results. Each of multiple linear regression models are statistically significant ( $p$-value of F-test is less than level of significance). The multi-collinearity is rejected for each partial model (PM1: VIF-value = 4.482; PM2: VIF-value $=3.698$ ). The normality of distributed errors was accepted for each PMs. The results of testing the significance of the thus designed general models are show in Tab. 5 .

The results (Tab. 5) show that the assumptions for applying MLRs are met in both models. Both factors (CF, FF) are statistically significant. The above GMs are statistically significant (GM1: p-value of F-test $=6.02 \mathrm{E}$ 06; GM2: p-value of F-test $=3.13 \mathrm{E}-06$ ). Multicollinearity does not negatively affect the results of estimated regression coefficients (GM1: VIF-values = 2.846; GM2: not calculate, because GM2 has two independent variables). Selected factors explain $3.6 \%$ variability of entrepreneurs'

\section{Tab. 3: Verification of the significance of the estimated coefficient and correlation}

\begin{tabular}{|c|c|c|c|c|c|}
\hline $\begin{array}{c}\text { Type } \\
\text { of mode }\end{array}$ & Regression equation & \multicolumn{4}{|c|}{ Independent variables } \\
\hline \multicolumn{2}{|c|}{ Indicators of factor - CF } & $\mathrm{CF}_{1}$ & $\mathrm{CF}_{2}$ & $\mathrm{CF}_{3}$ & $\mathrm{CF}_{4}$ \\
\hline \multirow{2}{*}{ PM1 } & Correlation (R) & 0.723 & 0.720 & 0.613 & 0.632 \\
\hline & SEC (t-test; p-value) & $2.14 \mathrm{E}-11$ & $2.18 \mathrm{R}-9$ & $1.82 \mathrm{E}-11$ & $1.71 \mathrm{E}-9$ \\
\hline \multicolumn{2}{|c|}{ Indicators of factor - FF } & $\mathrm{FF}_{1}$ & $\mathrm{FF}_{2}$ & $\mathrm{FF}_{3}$ & $\mathrm{FF}_{4}$ \\
\hline \multirow{2}{*}{ PM2 } & Correlation (R) & 0.593 & 0.659 & 0.641 & 0.601 \\
\hline & SEC (t-test; p-value) & $2.04 \mathrm{E}-12$ & 1.34R-11 & $3.41 \mathrm{E}-13$ & $1.47 \mathrm{E}-7$ \\
\hline
\end{tabular}




\section{Tab. 4: Characteristics of multiple linear regression of partial models}

\begin{tabular}{|c|c|c|}
\hline \multirow{2}{*}{$\begin{array}{l}\text { Characteristics of the } \\
\text { regression models }\end{array}$} & \multicolumn{2}{|c|}{ Type of partial model } \\
\hline & PM1 & PM2 \\
\hline MCC & 0.991 & 0.987 \\
\hline$R^{2}$ & 0.980 & 0.974 \\
\hline F-test (p-value) & 0.000 & 0.001 \\
\hline Type of model & \multicolumn{2}{|c|}{ MLR equation } \\
\hline PM1 & \multicolumn{2}{|c|}{$\mathrm{CF}=0.847 \times \mathrm{CF}_{1}+0.854 \times \mathrm{CF}_{2}+0.742 \times \mathrm{CF}_{3}+0.871 \times \mathrm{CF}_{4}$} \\
\hline PM2 & \multicolumn{2}{|c|}{$\mathrm{FF}=0.064 \times F F_{1}+0.054 \times F F_{2}+0.006 \times F F_{3}+0.14 \times F F_{4}$} \\
\hline
\end{tabular}

Note: PM1 - partial model for CF; PM2 - partial model for FF.

\section{Tab. 5: Verification of assumptions of MLRs}

\begin{tabular}{c|c|c|c}
\multicolumn{4}{c}{ Verification of the assumptions } \\
\hline \multicolumn{2}{c}{ General model } & CF & FF \\
\hline Selected factors of QBE & Bartlett's test & 0.024 & 0.007 \\
\hline Homoscedasticity & Z-score & 1.741 & 1.921 \\
\hline NDSS & & & \\
\hline
\end{tabular}

Source: own

\section{Tab. 6: Verification of the significance of the estimated coefficient and correlation}

\begin{tabular}{|c|c|c|c|c|c|c|c|c|c|}
\hline \multicolumn{10}{|c|}{ General model - GM2 } \\
\hline \multicolumn{2}{|c|}{ Independent variables } & \multicolumn{4}{|c|}{ CF } & \multicolumn{4}{|c|}{ FF } \\
\hline Correlation & $R$ & \multicolumn{4}{|c|}{0.190} & \multicolumn{4}{|c|}{0.142} \\
\hline SEC & t-test & \multicolumn{4}{|c|}{0.004} & \multicolumn{4}{|c|}{0.031} \\
\hline \multicolumn{10}{|c|}{ General model - GM1 } \\
\hline \multicolumn{2}{|c|}{ Independent variables } & $\mathrm{CF}_{1}$ & $\mathrm{CF}_{2}$ & $\mathrm{CF}_{3}$ & $\mathrm{CF}_{4}$ & $\mathrm{FF}_{1}$ & $\mathrm{FF}_{2}$ & $\mathrm{FF}_{3}$ & $\mathrm{FF}_{4}$ \\
\hline Correlation & $\mathrm{R}$ & 0.12 & 0.11 & 0.10 & 0.19 & 0.01 & 0.11 & 0.12 & 0.17 \\
\hline SEC & t-test & 0.21 & 0.30 & 0.91 & 0.01 & 0.14 & 0.76 & 0.32 & 0.01 \\
\hline
\end{tabular}

responses to $\mathrm{QBE}$. Independent variables (GM1: $\mathrm{CF}_{4}$ and $\mathrm{FF}_{4}$; GM2: $\mathrm{CF}$ and $\mathrm{FF}$ ) are statistically significant (GM1: $\mathrm{CF}_{4}, \mathrm{FF}_{4}-\mathrm{p}$-values of t-test are less than 0.05; GM2: CF, FF - p-values of t-test are also less than 0.05$)$. The normality of distributed errors was accepted for GM (GM1: $\mathrm{S}-\mathrm{W}$ test $=0.172 ; \mathrm{GM} 2$ : S-W test $=0.207)$. The hypotheses $H 1$ and $H 2$ were accepted.
A quality business environment creating suitable conditions is a basic prerequisite for the development of SMEs. Besides economic criteria, also noneconomic criteria (educational, cultural, legislative factors) play an essential role during this process. (Kozubikova et al., 2019; Dvorský et al., 2018). 


\section{Tab. 7: Characteristics of the regression GMs}

\begin{tabular}{c|c|c} 
General model (GM) & GM1 & GM 2 \\
\hline Multiple correlation coefficient & 0.243 & 0.197 \\
\hline Coefficient of determination & 0.059 & 0.036 \\
\hline F-test ( $p$-value) & $6.02 \mathrm{E}-06$ & $3.13 \mathrm{E}-06$ \\
\hline MLR equation (GM) & $\mathrm{QBE}=0.064 \times \mathrm{CF}_{1}-0.057$ & \\
& $\times \mathrm{FF}{ }_{1}+0.054 \times \mathrm{CF}_{2}+0.017$ & $\mathrm{QBE}=\mathbf{0 . 0 6 9} \times \mathbf{C F}+\mathbf{0 . 0 2 7} \times \mathbf{F F}$ \\
& $\times \mathrm{FF}_{2}+0.006 \times \mathrm{CF}_{3}+0.054$ & \\
& $\times \mathrm{FF}_{3}+\mathbf{0 . 1 4} \times \mathbf{C F}_{4}+\mathbf{0 . 1 3} \times \mathbf{F F}_{4}$ & \\
\hline
\end{tabular}

Source: own research

\section{Fig. 2: Results of LRM models for selected indicators (factors)}

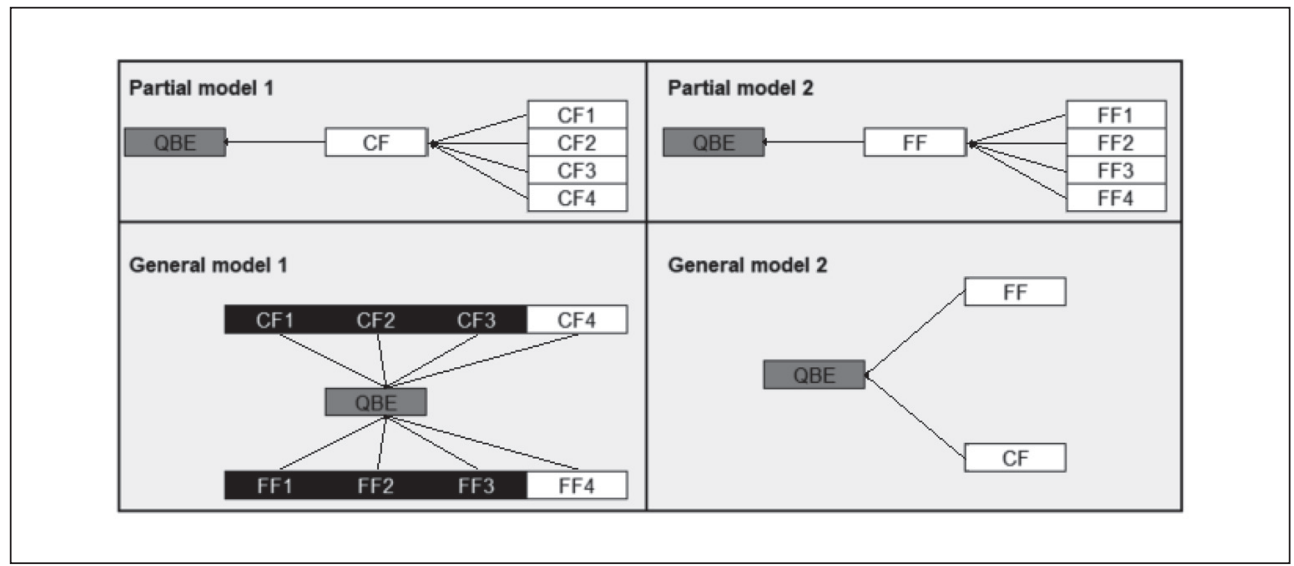

Fig. 2 shows the statistical significance of selected indicators (also factors), and their relationship to factors (partial model 1 and partial model 2) and to the quality of business environment (general model 1, general model 2).

The statistically significant indicator or factor is white color (e.g., FF, CF), the not statistically significant indicator or factor is black color (e.g., CF1, FF2) and the dependent variable is gray color on the Fig. 2. Results showed interesting findings.

The authors place CR and SR companies together into one data set. The authors think that the business environment in the two countries is very strongly intertwined. The relationships between countries are based on similar languages, the number of SMEs and their structure by sector with regard to SME demographics, the sales of SMEs, and the employment of SMEs (Slovak Business Agency, 2018).

The most important indicator of the competitive environment (CF) is that suppliers in the SME segment demand reasonable prices for their products and services. On the contrary, the least significant indicator of the competitive environment is the appropriate intensity of competition in the sector. The most important indicator of a narrower business environment (FF) is that employees are working hard to meet business goals. Conversely, the least significant indicator of a narrower business environment is the support of suppliers to achieve business goals in the SME segment. 
The competitive environment and the narrower business environment therefore have a significant impact on the overall quality of the business environment in the SME segment. We found that both the factors we selected (CF and FF) were statistically significant. The competitive environment (CF) has a greater impact on the quality of the business environment than the narrower business environment (FF). Human capital in the form of employees and the adequacy of supplier prices are indicators that have a significant impact on the quality of the business environment in the SME segment.

The results of our research are mostly compatible with the findings Soetanto et al. (2010), Naudé et al. (2008), Sternberg and Wennekers (2005), who emphasize the impact of economic factors on start-up, and also with an approach of Sinha et al. (2011), MarantoVargas and Rangel (2007) and McDowell et al. (2010), who point to the impact of essential factors of a narrower competitive environment on start-up.

Our research has also highlighted the great importance of human capital in companies. This effect can be seen on two levels. The first is the importance of human capital for the company in the form of a production factor. Human capital is a factor of production that enters the production process in which it creates added value. It can therefore be stated that the foundation of a prosperous business is quality human resources.

The second area is the importance of education for SMEs. Higher education of entrepreneurs has a positive impact on the ability to manage business risks in a company, enables better understanding of financial market situations and better management of financial risks in a company (Rahman et al., 2017; Kozubíková et al., 2015).

\section{Conclusions}

The aim of this article was to identify important factors of competitiveness which impact startup in segment of small and medium-sized enterprises in the Czech and the Slovak Republic.

Based on our own research, we found that both the competitive environment (CF) and the narrower business environment (FF) affect the overall quality of the business environment in the SME segment and also have an impact on start-ups. It has also been shown that human capital in the form of employees is the most critical indicator of a narrower business environment (FF). The most important indicator of a competitive environment (CF) is that business suppliers demand reasonable prices for services and products.

Our research has shown that the QBE is a current researched and discussed topic that is in the interest of the state and non-state institutions and its perceptions also affect the motives and willingness to enter the business environment. At the same time, it is important to note the fact that the QBE is also affected by the businesses themselves. Their behavior influences the perception of the QBE by the public, but contrary the perception of the position of the entrepreneurs in society significantly shapes the character and nature of the business environment.

Despite of our awareness of the specified limits to our research (e.g., local character of the study - only two countries; simple size 641 enterprises; statistical methodology - only MLRs), we believe that our article has brought several interesting findings and new incentives for the further research and discussion regarding the quality of the business environment, their factors and possibilities for the improvement.

It is worth to concentrate our future research on the examination of the other factors influencing the quality of the business environment (social, economic, political and technologic factors) and on their indicators in the segment of SMEs to improve business environment.

\section{References}

Abrhám, J., Bilan, Y., Krauchenia, A., \& Strielkowski, W. (2015). Planning horizon in labour supply of Belarusian small entrepreneurs. Economic Research - Ekonomska Istraživanja, 28(1), 773-787. https://doi.org/10.1080/133167 7X.2015.1084238

Ajaz Khan, K., Çera, G., Nétek, V. (2019). Perception of the Selected Business Environment Aspects by Service Firms. Journal of Tourism and Services, 10(19), 111-127. https://doi.org/10.29036/jots.v10i19.115

Arauzo-Carod, J. M., \& Segarra-Blasco, A. (2005). The Determinants of Entry Are Not Independent of Start-Up Size: Some Evidence from Spanish Manufacturing. Review of Industrial Organization, 27(2), 147-165. https://doi.org/10.1007/s11151-005-8321-z 
Balcaen, S., \& Ooghe, H. (2006). 35 Years of Studies on Business Failure: An Overview of the Classic Statistical Methodologies and Their Related Problems. British Accounting Review, 38(1), 63-93. https://doi.org/10.1016/j. bar.2005.09.001

Barba-Sánchez, V., \& Atienza-Sahuquillo, C. (2011). Reasons to Create a New Venture: A Determinant of Entrepreneurial Profiles. African Journal of Business Management, 5(28), 1149711504. https://doi.org/10.5897/AJBM11.1131

Belás, J., Cipovová, E., \& Demjan, V. (2014). Current Trends in Area of Satisfaction of Bank Clients in the Czech Republic and Slovakia. Tranformations in Business and Economics, 13(3), 219-234.

Belás, J., Ključnikov, A., \& Smrčka, L. (2016). Motives for Entrepreneurship. Case Study from the World of SMEs. Scientific Papers of the University of Pardubice Series $D$, 24(3), 5-17.

Belás, J., \& Gabčová, L. (2016). The Relationship among Customer Satisfaction, Loyalty and Financial Performance of Commercial Banks. E\&M Economics and Management, 19(1), 132-147. https://doi. org/10.15240/tul/001/2016-1-010

Belas, J., Smrcka, L., Gavurova, B., \& Dvorsky, J. (2018). The Impact of Social and Economic Factors in the Credit Risk Management of SME. Technological and Economic Development of Economy, 24(3), 1215-1230. https://doi.org/10.3846/tede.2018.1968

Bilan, Y., Gavurova, B., Stanisław, G., \& Tkacova, A. (2017). The Composite Coincident Indicator $(\mathrm{CCl})$ for Business Cycles. Acta Polytechnica Hungarica, 14(7), 71-90. https://doi.org/10.12700/aph.14.7.2017.7.5

Boeck, H., Bendavid, Y., \& Lefebvre, E. (2009). Evolving B2B E-commerce Adaptation for SME Suppliers. Journal of Business \& Industrial Marketing, 24(8), 561-574. http://doi. org/10.1108/08858620910999439

Brink, T. (2017). SME Routes for Innovation Collaboration with Larger Enterprises. Industrial Marketing Management, 64, 122-134. https://doi.org/10.1016/j.indmarman.2017.01.010

Buganová, K., \& Moricová, V. (2017). Innovation of Education in Risk and Crisis Management. Turkish Online Journal of Educational Technology, 16(November Special Issue for INTE), 177-182.

Capó-Vicedo, J., Expósito-Langa, M., \& Molina-Morales, F. X. (2008). Improving
SME Competitiveness

Reinforcing

Interorganisational Networks in Industrial Clusters. International Entrepreneurship and Management Journal, 4(2), 147-169. https://doi.org/10.1007/s11365-007-0059-7

Cera, G., Mlouk, A., Cera, E., \& Shumeli, A. (2020). The Impact of Entrepreneurship Education on Entrepreneurial Intention. A Quasi-Experimental Research Design. Journal of Competitiveness, 12(1), 39-56. https://doi.org/10.7441/joc.2020.01.03

Conorto, R., Dlhopolček, J., Kopečný, P., Maxin, R., Tonka, V., Tvrdoň, J., Vajdová, E., \& Vyšný, T. (2014). Analýza, monitor kvality podnikatel'ského prostredia $v$ SR a konkurencieschopnost' ekonomiky (Project Report). Bratislava: Federation of employers' associations of the Slovak Republic. Retrieved February 2, 2020, from http://www.azzz.sk/wp-content/uploads/ 2015/05/Anal\%C3\%BDza-monitor-kvalitypodnikate\%C4\%BEsk\%C3\%A9ho-prostredia-vSR-a-konkurencieschopnos\%C5\%A5-ekonomiky. pdf

Coppa, M., \& Sriramesh, K. (2013). Corporate social responsibility among SMEs in Italy. Public Relations Review, 39(1), 30-39. https://doi.org/10.1016/j.pubrev.2012.09.009

de Waal, D. J. (1977). Asymptotic Distributions for the Elementary Symmetric Functions of Two Matrices under the Assumption of Linearity. Journal of Multivariate Analysis, 7(1), 223-228. https://doi.org/10.1016/0047259X(77)90042-2

Dvorský, J., Petráková, Z., Ajaz Khan, K., Formánek, I., \& Mikoláš, Z. (2020). Selected Aspects of Strategic Management in the Service Sector. Journal of Tourism and Services, 20(11), 109-123. https://doi.org/10.29036/jots. v11i20.146

Dvorský, J., Schönfeld, J., Kotásková, A., \& Petráková, Z. (2018). Evaluation of Important Credit Risk Factors in the SME Segment. Journal of International Studies, 11(3), 204-216. https://doi.org/10.14254/20718330.2018/11-3/17

Fernández-Olmos, M., \& RamírezAlesón, M. (2017). How Internal and External Factors Influence the Dynamics of SME Technology Collaboration Networks over Time. Technovation, 64-65, 16-27. https://doi. org/10.1016/j.technovation.2017.06.002

Fyliuk, H., Honchar, I., \& Kolosha, V. (2019). The Interrelation between Economic Growth and National Economic Competitiveness: The Case 
of Ukraine. Journal of Competitiveness, 11(3), 53-69. https://doi.org/10.7441/joc.2019.03.04

Games, D., \& Roliza, R. (2019). SME Internal Capability and Competitive Advantage in an Emerging Market: Moderating Effects of Firm Age. AMAR - Andalas Management Review, 3(1), 103-114. https://doi.org/10.25077/ amar.3.1.103-114.2019

GE Money Bank. (2010). Motivy, které vedou lidi k podnikání. Retrieved February 2, 2020, from http://ekonomika.idnes.cz/specialnipriloha.aspx?y=ekonomika\%2Fmotivy-kterevedou-lidi-k-podnikani.htm

Gleave, W., \& Mitra, J. (2009). The Spatial Determinants of Entrepreneurship in the Regions of England, 2000-2004. International Journal of Entrepreneurship and Small Business, 9(2), 143-161. https://doi. org/10.1504/IJESB.2010.030617

Hess, J. P. (2020). Entrepreneurial ecosystems in Bulgaria and Romania: A comparative analysis. Thunderbird International Business Review, 62(5), 489-501. https://doi.org/10.1002/ tie.22154

Hikkerova, L., Ilouga, S. N., \& Sahut, J.-M. (2016). The Entrepreneurship Process and the Model Violation. Journal of Business Research, 69(5), 1868-1873. https://doi.org/10.1016/j. jbusres.2015.10.071

Hudakova, M., Masar, M., Luskova, M., Patak, M. R. (2018). The Dependence of Perceived Business Risks on the Size of SMEs. Journal of Competitiveness, 10(4), 54-69. https://doi.org/10.7441/joc.2018.04.04

Huo, D., Chen, Y., Hung, K., Song, Z., Guan, J., \& Ji, A. (2019). Diamond model and the export competitiveness of the agriculture industry from emerging markets: An exploratory vision based on a spatial effect study using a genetical gorithm. Economic Research - Ekonomska Istraživanja, 33(1), 2427-2443. https://doi.org/ 10.1080/1331677X.2019.1679212

Chew, Y.-T., \& Yeung, H. W.-C. (2001). The SME Advantage: Adding Local Touch to Foreign Transnational Corporations in Singapore. Regional Studies, 35(5), 431-448. https://doi. org/10.1080/713693823

Islam, M. (2019). Starting Up New Business through Instagram: Cases from South Korea. International Journal of Innovative Technology and Exploring Engineering, 8(12), 2426-2428. https://doi.org/10.35940/ijitee.L3010.1081219
Ivanová, E., \& Čepel, M. (2018). The Impact of Innovation Performance on the Competitiveness of the Visegrad 4 Countries. Journal of Competitiveness, 10(1), 54-72. https://doi.org/10.7441/joc.2018.01.04

Jakubec, V., Sobekova, M., \& Solik, J. (2011). Prieskum potrieb mladých podnikatelov a prekážok v ich podnikaní. Bratislava: luventa.

Ketko, N. V., \& Akimova, O. E. (2016). Analyzing, Evaluating and Ranking of Motivational Preferences of Entrepreneurs in Small Business Development. Actual Problems of Economics, 175(1), 361-369.

Kliestik, T., Misankova, M., Valaskova, K., \& Svabova, L. (2018). Bankruptcy Prevention: New Effort to Reflect on Legal and Social Changes. Science and Engineering Ethics, 24(2), 791803. https://doi.org/10.1007/s11948-017-9912-4

Ključnikov, A., Civelek, M., Čech, P., \& Kloudová, J. (2019). Entrepreneurial orientation of SMEs' executives in the comparative perspective for Czechia and Turkey. Oeconomia Copernicana, 10(4), 773-795. https://doi. org/10.24136/oc.2019.035

Ključnikov, A., Belás, J., \& Smrčka, L. (2016). The Role of Risk-taking and Competitive Aggressiveness in Management of SMEs. Polish Journal of Management Studies, 14(1), 129-139. https://doi.org/10.17512/ pjms.2016.14.1.12

Kot, S., Meyer, N., \& Broniszewska, A. (2016). A cross-country comparison of the characteristics of Polish and South African woman entrepreneurs. Economics \& Sociology, 9(4), 207-221. https://doi.org/10.14254/2071789X.2016/9-4/13

Kozubikova, L., Kotaskova, A., Dvorsky, J., \& Kljucnikov, A. (2019). The Impact Of Political Factors' Perception on Suitability of International Business Environment: The Case of Startups. Economics and Sociology, 12(1), 61-79. https://doi.org/10.14254/2071789X.2019/12-1/3

Kozubíková, L., Belás, J., Ključnikov, A., \& Virglerová, Z. (2015). Differences in Approach to Selected Constructs of Entrepreneurial Orientation in SME Segment Regarding the Selected Socio-Demographic Factors. Transformation in Business and Economic, 14(3C), 333-355.

Krajnakova, E., Navickas, V., \& Kontautiene, R. (2018). Effect of macroeconomic business environment on the development of corporate social responsibility in Baltic Countries and 
Slovakia. Oeconomia Copernicana, 9(3), 477-492. https://doi.org/10.24136/oc.2018.024

Lancaster, H. O., \& Hamdan, M. A. (1964). Estimation of The Correlation Coefficient in Contingency Tables with Possibly Nonmetrical Characters. Psychometrika, 29(4), 383-391. https://doi.org/10.1007/BF02289604

Lewandowska, A., \& Stopa, M. (2019). Do SME's innovation strategies influence their effectiveness of innovation? Some evidence from the case of Podkarpackie as peripheral region in Poland. Equilibrium. Quarterly Journal of Economics and Economic Policy, 14(3), 521-536. https://doi.org/10.24136/eq.2019.025

Li, L., Su, F., Zhang, W., \& Mao, J.-Y. (2018). Digital Transformation by SME Entrepreneurs: A Capability Perspective. Information Systems Journal, 28(6), 1129-1157. https://doi. org/10.1111/isj.12153

Maranto-Vargas, D., \& Rangel, R. G.-T. (2007). Development of Internal Resources and Capabilities as Sources of Differentiation of SME under Increased Global Competition: A Field Study in Mexico. Technological Forecasting and Social Change, 74(1), 90-99. https://doi.org/10.1016/j.techfore.2005.09.007

McDowell, W. C., Harris, M. L., \& Gibson, S. G. (2010). The Impact of Trust and Dependency on Business Performance: A Study of SME Suppliers. Small Business Institute Journal, 6(1), 41-62.

Meyer, N., Molefe, K., \& De Jongh, J. J. (2018). Managerial challenges within SMEs: The case of a developing region. Polish Journal of Management Studies, 18(2), 185-196. https://doi.org/10.17512/pjms.2018.18.2.15

Naudé, W., Gries, T., Wood, E., \& Meintjies, A. (2008). Regional Determinants of Entrepreneurial Start-Ups in a Developing Country. Entrepreneurship and Regional Development, 20(2), 111-124. https://doi. org/10.1080/08985620701631498

Ngoc Mai, A., Van Vu, H., Xuan Bui, B., \& Quang Tran, T. (2019). The lasting effects of innovation on firm profitability: panel evidence from a transitional economy. Economic Research - Ekonomska Istraživanja, 32(1), 3411-3430. https://doi.org/10.1080/1331677X.2019.1660199

Niefert, M. (2010). Characteristics and Determinants of Start-Ups from Unemployment: Evidence from German Micro Data. Journal of Small Business \& Entrepreneurship, 23(3), 409-429. https://doi.org/10.1080/08276331.20 10.10593493
Nunes, S., Grilo, H., Lopes, R., \& Martins, O. (2018). Innovation and Firm Economic Performance: Evidence from Portuguese SME. In V Workshop on Computational Data Analysis and Numerical Methods - Book of Abstracts (pp. 80-81). Felgueiras, Portugal. Retrieved February 2, 2020, from https://dspace. uevora.pt/rdpc/bitstream/10174/23700/1/Livro Resumos_Final.pdf

O'Brien, R. M. (2007). A Caution Regarding Rules of Thumb for Variance Inflation Factors. Quality and Quantity, 41(5), 673-690. https:// doi.org/10.1007/s11135-006-9018-6

Plotnikova, M., Romero, I., \& MartínezRomán, J. A. (2016). Process Innovation in Small Business: The Self-Employed as Entrepreneurs. Small Business Economics, 47(4), 939-954. https://doi.org/10.1007/ s11187-016-9743-8

PwC. (2010). Pro české podnikatele může být snažši zvládnout hospodářskou krizi, než uřídit růst své firmy (Press Release). Prague: PwC Czech Republic. Retrieved February 2, 2020, from https://www.pwc.com/ cz/cs/zkouska-ohnem/zkouska-ohnem-tiskovazprava.jhtml

Rahman, A., Belas, J., Kliestik, T., \& Tyll, L. (2017). Collateral Requirements for SME Loans: Empirical Evidence from the Visegrad Countries. Journal of Business Economics and Management, 18(4), 650-675. https://doi.org/1 0.3846/16111699.2017.1357050

Rowland-Jones, R., Thomas, P. T., \& PageThomas, K. (2008). Quality Management tools \& techniques: profiling SME use \& customer expectations. The International Journal for Quality and Standards, 1(6), 1-17.

Rusu, V.-D., \& Roman, A. (2018). An empirical analysis of factors affecting competitiveness of C.E.E. countries. Economic Research - Ekonomska Istraživanja, 31(1), 2044-2059. https://doi.org/10.1080/133167 7X.2018.1480969

Saleh, A., Yordan, A., \& Buang, N. A. (2019). Global Competitiveness of Riau Small and Medium Enterprise (SME) Special Food Products Entrepreneur in Pekanbaru, Sumatera, Indonesia. Journal of Multidisciplinary Academic, 3(1), 42-47.

Shaykhutdinova, G. F., Zhidkova, E. V., Minisheva, L. V., Nikolinova, S. A., \& Sharipova, I. M. (2015). Actual Problems of Youth Entrepreneurship at the Modern Stage. Journal of Advance Research in Law and Economics, 
6(2), 378-385. https://doi.org/10.14505/jarle. v6.2(12). 14

Simionescu, M., \& Naroş, M.-S. (2019). The Role of Foreign Direct Investment in Human Capital Formation for a Competitive Labour Market. Management Research and Practice, 11(1), 5-14.

Sinha, P., Akoorie, M. E., Ding, Q., \& Wu, Q. (2011). What Motivates Manufacturing SMEs to Outsource Offshore in China? Comparing the Perspectives of SME Manufacturers and Their Suppliers. Strategic Outsourcing: An International Journal, 4(1), 67-88. https://doi. org/10.1108/17538291111108435

Slovak Business Agency. (2018). Comparison of business conditions SMEs in Central European countries. Slovak Business Agency. Retrieved June 28, 2020, from https://www.npc.sk/media/uploads/files/ Porovnanie_podmienok_podnikania_MSP_v_ krajinach_strednej_Europy_II3158H.pdf

Soetanto, D. P., Pribadi, H., \& Widyadana, G. A. (2010). Determinant Factors of Entrepreneurial Intention Among University Students. IUP Journal of Entrepreneurship Development, 7(1/2), 23-37.

Staniewski, M., \& Awruk, K. (2015). Motivating Factors and Barriers in The Commencement of One's Own Business for Potential Entrepreneurs. Economic Research, 28(1), 583-592. https://doi.org/10.1080/13316 77X.2015.1083876

Sternberg, R., \& Wennekers, S. (2005). Determinants and Effects of New Business Creation Using Global Entrepreneurship Monitor Data. Small Business Economics, 24(3), 193203. https://doi.org/10.1007/s11187-005-1974-z

Srpová, J., \& Řehoř, V. (2010). Základy podnikání. Prague: Grada.

Šabić-Lipovača, A., Strielkowski, W., \& Bilan, Y. (2016). Intertemporal substitution and labour supply of Bosnian SME's. Amfiteatru Economic Journal, 18(43), 634-653.
Tan, E. N., Smith, G., \& Saad, M. (2006). Managing the Global Supply Chain: A SME Perspective. Production Planning \& Control, 17(3), 238-246. https://doi. org/10.1080/09537280500285417

Valaskova, K., Kliestik, T., \& Kovacova, M. (2018). Management of Financial Risks in Slovak Enterprises Using Regression Analysis. Oeconomia Copernicana, 9(1), 105-121. https://doi.org/10.24136/oc.2018.006

Van Stel, A., Lokshin, B., \& de Vries, N. (2019). The Effect of SME Productivity Increases on Large Firm Productivity in the EU. Kyklos, 72(2), 332-353. https://doi.org/10.1111/ kykl.12198

Westerlund, M., Rajala, R., \& Leminen, S. (2008). SME Business Models in Global Competition: A Network Perspective. International Journal of Globalisation and Small Business, 2(3), 342-358. https://doi. org/10.1504/IJGSB.2008.017294

Wyld, J., Pugh, G., \& Tyrrall, D. (2012). Can Powerful Buyers "Exploit" SME Suppliers? Journal of Small Business and Enterprise Development, 19(2), 322-334. https://doi. org/10.1108/14626001211223928

Yadav, V., Sharma, M. K., \& Singh, S. (2018). Intelligent Evaluation of Suppliers Using Extent Fuzzy TOPSIS Method: A Case Study of An Indian Manufacturing SME. Benchmarking: An International Journal, 25(1), 259-279. https://doi.org/10.1108/BIJ-07-2016-0114

Zheng, M., \& Yu, W. (2015). Linear Regression Analysis with Inequality Constraints on the Regression Parameters via Empirical Likelihood. Journal of Statistical Computation and Simulation, 85(9), 1782-1792. https://doi. org/10.1080/00949655.2014.902459

Zygmunt, J. (2018). Entrepreneurial activity drivers in the transition economies. Evidence from the Visegrad countries. Equilibrium. Quarterly Journal of Economics and Economic Policy, 13(1), 89-103. https://doi.org/10.24136/ eq.2018.005 